\title{
Material flow analysis and life cycle assessment of solid waste management in urban green areas, Thailand
}

\author{
Indika Thushari ${ }^{1}$, Juckrit Vicheanteab ${ }^{1}$ and Dao Janjaroen ${ }^{1,2^{*}}$ (D)
}

\begin{abstract}
This study presents solid waste management planning in an urban green area, Bangkok, Thailand based on the material flow analysis (MFA) and life cycle assessment (LCA). Global warming potential (GWP) of four scenarios for handling solid waste generated in Chulalongkorn University Centenary Park, 2018 was assessed concerning the different ratios of waste recycling, composting, incineration, and landfilling. The results show that alternative systems proposed will result in lower GWP than the existing waste management strategy. The MFA results reveal that the final weights of solid waste ending up in a landfill are 98.8, 101.9, 68.2, and $44.8 \mathrm{t} \mathrm{yr}^{-1}$ for scenarios 1, 2, 3, and 4 , respectively. Increased rates of landfill diversion by increased recycling, composting, and incineration decreased the quantity of solid waste disposed to the landfill and improved the environmental profile of the park waste management system. The LCA results found landfilling to be the dominant source of greenhouse gas (GHG) burdens, while waste recycling was found to result in the reduction of GHG. The results highlight that the use of MFA and LCA as a combined tool to evaluate the environmental performance of solid waste management systems provides valuable information for policy and decision-makers.
\end{abstract}

Keywords: Solid waste management, Global warming potential, Urban green areas, Material flow analysis, Life cycle assessment

\section{Introduction}

Municipal solid waste (MSW) management is a critical issue in Thailand. In 2015, Thailand generated $26.9 \mathrm{Mt}$ of MSW national wide, $16 \%$ of which was generated alone in the country's capital, Bangkok. Even though the composition varies due to urbanization, population density, and income in different areas, the MSW in Thailand typically consists of about $51 \%$ of green/organic waste, $22 \%$ of plastic, $13 \%$ of paper, and $3 \%$ of glass. Pollution Control Department (PCD) has stated that $54 \%$ of collected waste in Thailand is properly disposed of, while the rest is incorrectly disposed of as open burning or illegal burning. The absence of an effective

\footnotetext{
* Correspondence: dao.s@chula.ac.th

'Department of Environmental Engineering, Faculty of Engineering, Chulalongkorn University, Bangkok 10330, Thailand

${ }^{2}$ Research Unit Control of Emerging Micropollutants in Environment, Chulalongkorn University, Bangkok 10330, Thailand
}

integrated waste management system in the country creates many environmental, economic, and social problems [1, 2]. Figure S1 in Supplemental Material depicts the current waste management practices in Thailand.

The waste management sector in any country is under increasing pressure to improve its environmental performance [3]. Solid waste management (SWM) is often a local responsibility in most countries. Limited resources and the capacity in local authorities as well as poor implementation of targeted legislation challenge sustainable waste management practices in low- and middle-income countries compared to that in higher-income countries. Therefore, higher-income countries precede towards sustainable waste management practices. Source reduction is the most favored waste management practice from the sustainable waste management hierarchy. Higher-income countries have achieved a higher level of

(c) The Author(s). 2020 Open Access This article is licensed under a Creative Commons Attribution 4.0 International License, which permits use, sharing, adaptation, distribution and reproduction in any medium or format, as long as you give appropriate credit to the original author(s) and the source, provide a link to the Creative Commons licence, and indicate if changes were made. The images or other third party material in this article are included in the article's Creative Commons licence, unless indicated otherwise in a credit line to the material. If material is not included in the article's Creative Commons licence and your intended use is not permitted by statutory regulation or exceeds the permitted use, you will need to obtain permission directly from the copyright holder. To view a copy of this licence, visit http://creativecommons.org/licenses/by/4.0/. 
progress in waste reduction as well as advanced recycling practices even though the rate of waste generation is higher than that in low and middle-income countries [2-4]. Efficient waste separation at the source makes composting/anaerobic digestion, and incineration is easier and effective. The practice of composting in low- and mid-income countries is less popular despite the high organic content in MSW due to contamination and the operating cost of the large plants. Advancing waste incineration with environment controllers and energy recovery systems are widely used in high-income countries with low-land availability [2-4]. However, globally most MSW is openly dumped or disposed of to a landfill (Fig. S1) [4]. In general, SWM contributes to $5 \%$ of global greenhouse gas (GHG) emissions [4]. Global warming and climate change due to an increased level of GHG is a serious global concern. Therefore, sustainable MSW management is a crucial aspect that should be addressed in an integrated approach in Thailand as a leading country in developing Asia. The most popular waste disposal method in Thailand is landfilling [1, 2]. Landfilling has many negative environmental impacts. This practice contributes to climate change on a global scale due to the emission of a large amount of GHG from the degradation of organic materials. Besides landfilling, incineration and composting are other popular, yet less used methods of MSW management in Thailand [2]. Waste recycling shows a significant contribution to GHG mitigation due to the possible substitution of virgin material production, thus considered as a sustainable waste management option [5]. Therefore, the improvement of SWM systems in terms of recovering values in the form of materials and energy would enhance resource efficiency and GHG mitigation potentials [5].

Urban green areas are becoming increasingly important due to the increased rate of urbanization, and their role in maintaining a healthy population and economy in any developed or developing city [6, 7], such as Bangkok, Thailand. Maintenance and user activities in these urban green parks generate a considerable amount of solid wastes which ends up as a major contributor to the increasing generation of MSW [8]. Therefore, the assessment of potential treatment methods of such waste is important in policy and decision-making initiatives. Shi et al. [9] and Raud et al. [10] have reported the utilization potential of lignocellulose waste generated in urban parks for biofuel production in China and Estonia, respectively. However, environmental assessments of the treatment of garden wastes are reported only in a few studies in the literature $[8,11]$. The Chulalongkorn University Centenary Park (CUCP) is a recently built multi-purpose urban forest that serves as a quality green space for the residents of the surrounding community. Many organized public activities and the increasing number of visitors in the park contribute to a considerable amount of solid waste generation. This heightens the necessity of sustainable waste management for the park.

Integrated material flow analysis (MFA) and life cycle assessment (LCA) has become an increasingly recommended method for decision making in SWM systems. MFA on the levels of goods helps in understanding the functioning of processes and connection between processes in waste management by acting as an excellent tool for analyzing, and managing flows of wastes, secondary products, and residues [12]. LCA evaluates environmental benefits and burdens associated with waste management systems. LCA analyses system performance and allows comparison of alternatives while enabling the identification of possible system improvements [13]. Table 1 presents an overview of recent applications of MFA and LCA as a tool to support waste management decision making. Turner et al. [3] (environmental performance of MSW system in Wales); Sevigne-Itoiz et al. [14] (Spanish paper and cardboard recycling system); Nakem et al. [15] (Polyvinyl chloride waste management in Thailand); Padeyanda et al. [16] (food waste management in Daejeon Metropolitan City in Korea); Haupt et al. [17] (environmental performance of MSW management in Switzerland in 2012); demonstrated the use of complementary methodologies of MFA and LCA in combination to assess the environmental performance of waste management systems. Nevertheless, the use of MFA and LCA as an integrated assessment tool for MSW management in Thailand is almost non-existing in the literature. Therefore, environmental assessments of SWM should be based on the flows described by MFA and quantified using LCA, because such assessments provide valuable and transparent information for decision making.

Strong waste management policies that guide local actions promote sustainable waste management practices. Information on the current status of waste generation patterns and evaluation of available management systems are critical in revising and implementing policies. Also, this directs local governments to select appropriate management practices for future demand. Therefore, systematic evaluation of SWM in the CUCP is necessary to identify and overcome the shortcomings of the current practice. Thus, the main focus of the present study is to quantify the mass balances of the solid waste in CUCP, Bangkok, Thailand, and secondly to provide an environmental evaluation of a range of waste management options with regards to GHG emissions/Global Warming Potential (GWP). Identification of the contribution of waste streams and the treatment process for GWP will support decision and policy making practice in the local waste management sector in Thailand. 
Table 1 Application of MFA and LCA on waste management

\begin{tabular}{|c|c|c|c|c|c|c|}
\hline Application & Waste type & Geographical scope & Functional unit & Impact coverage & Conclusions & ief \\
\hline$\overline{M F A} / \mathrm{LCA}$ & MSW & $\begin{array}{l}\text { the city of } \\
\text { Cardiff, Wales }\end{array}$ & $\begin{array}{l}\text { Management of } \\
168,526 \text { t of MSW } \\
\text { in Cardiff, collected } \\
\text { between April } 2012 \\
\text { and March } 2013\end{array}$ & GHG & $\begin{array}{l}\text { - Evaluate a complex, } \\
\text { multi waste stream } \\
\text { at the meso- level. } \\
\text { - Demonstrates the use } \\
\text { of complementary } \\
\text { methodologies of } \\
\text { MFA and LCA in } \\
\text { combination to } \\
\text { provide valuable } \\
\text { information about } \\
\text { the environmental } \\
\text { performance of a } \\
\text { SWM system. }\end{array}$ & {$[3]$} \\
\hline MFA/consequential LCA & $\begin{array}{l}\text { Waste paper } \\
\text { and cardboard }\end{array}$ & Spain & $\begin{array}{l}\text { Recycling of } 1 \mathrm{t} \text { of } \\
\text { waste paper collected } \\
\text { in Spain (Nationally } \\
\text { and internationally) }\end{array}$ & GHG & $\begin{array}{l}\text { - The future GHG } \\
\text { quantifications should } \\
\text { be based on the flows } \\
\text { described by MFA and } \\
\text { quantified using } \\
\text { consequential LCA } \\
\text { because methodologies } \\
\text { that accurately account } \\
\text { for GHG are necessary } \\
\text { for decision-making. }\end{array}$ & {$[14$} \\
\hline MFA/LCA & $\begin{array}{l}\text { Polyvinyl chloride } \\
\text { (PVC)waste }\end{array}$ & Thailand & $\begin{array}{l}\text { Management of } \\
\text { post-consumer PVC } \\
\text { waste generated } \\
\text { during 2013-2014 }\end{array}$ & GWP, Energy use & $\begin{array}{l}\text { - MFA successful estimated } \\
\text { PVC waste flows while LCA } \\
\text { evaluated environmental } \\
\text { impacts of PVC waste } \\
\text { management }\end{array}$ & [15] \\
\hline MFA/LCA & Food waste & $\begin{array}{l}\text { Daejeon } \\
\text { Metropolitan } \\
\text { City in Korea. }\end{array}$ & $\begin{array}{l}\text { Management of } \\
1 \mathrm{t} \text { of food waste } \\
\text { generated from } \\
\text { households and } \\
\text { small-scale } \\
\text { restaurants }\end{array}$ & $\begin{array}{l}\text { GWP, Acidification } \\
\text { potential, } \\
\text { Eutrophication } \\
\text { potential, and } \\
\text { photochemical } \\
\text { ozone creation } \\
\text { potential }\end{array}$ & $\begin{array}{l}\text { - MFA and LCA were used } \\
\text { to quantify the potential } \\
\text { environmental impacts of } \\
\text { food waste management. }\end{array}$ & 161 \\
\hline MFA/LCA & MSW & Switzerland & $\begin{array}{l}\text { Treatment of all } \\
\text { MSW generated in } \\
\text { Switzerland, } 2012 \text {. }\end{array}$ & $\begin{array}{l}\text { Cumulative exergy } \\
\text { demand climate } \\
\text { change, human } \\
\text { toxicity and eco- } \\
\text { toxicity }\end{array}$ & $\begin{array}{l}\text { - The modular MFA/LCA } \\
\text { design allows for a } \\
\text { detailed assessment of } \\
\text { recycling and thermal } \\
\text { treatment pathways as } \\
\text { well as national waste } \\
\text { management strategies. }\end{array}$ & 177 \\
\hline
\end{tabular}

\section{Methodology}

\section{Goal and scope definition}

The CUCP is located in the center of Bangkok, Thailand, providing a quality green space for the surrounding communities. Figure S2 shows the location of the CUCP. The park plays a vital role in addressing some major environmental issues, such as water management and urban heat island effect in a rapidly developing city with climate change vulnerability [18]. An increasing number of visitors, as well as many activities organized in the park and the contiguous communities, generate a substantial amount of solid waste per day.

The main goal of the study is two-fold: to quantify the mass balance of the existing SWM system, and to quantitatively evaluate the GWP of current SWM and potential alternative systems.
Sampling was done twice a day (day and night time), 2 days a week (weekday and weekend day) throughout 2018, to quantify solid waste generation in the park. Waste collected from the publicly available waste bins and the garden was sorted and weighed at the site. A combination of methodologies, such as MFA and LCA was applied to assess the current SWM system and the possible alternative systems including national policy targets. MFA is a systematic assessment of flows and stocks of materials within an arbitrarily complex system defined in space and time [19]. Mass flows and the stocks of the waste management systems were calculated using MFA. The environmental impacts of the defined waste management systems were assessed using LCA. The assessment followed the ISO 14040 and 14,044 standards for LCA [20, 21]. 


\section{System boundaries and scenarios}

The functional unit (FU) was defined as the management of 112.4t of solid waste collected in the CUCP in 2018. The SWM system comprised a foreground system and background system. The foreground system directly involved with the reference flow management and the background system linked with the foreground system included energy production and avoided materials.

All the activities required managing the waste from their point of collection and onsite sorting, transportation, treatment, and final disposal were assessed to evaluate the waste management system comprehensively. The 'zero burden assumption' was made, whereby the environmental impacts from the upstream life cycle stages before the waste collection were not included [3, 22]. Only the direct consequences of waste management in selected scenarios were considered. Environmental impacts of the infrastructures and capital goods and wastewater from the treatment plants were also excluded similar to assumptions made by $[3,8,23]$. This is because they were less important to the overall results of scenario comparison. This allows the comparison of the many scenarios in a simple way [8].

System boundaries of the SWM system were defined according to cradle to grave principle and are presented in Fig. 1. Four scenarios for handling and treating the generated park waste were compared in the study.

S1 (scenario 1) represents the most common and simplified SWM system, which involves total recycling of all recyclable wastes, such as plastic, glass, paper, and aluminium/steel cans, and disposal of the rejects and the rest of the garden waste directly to a conventional landfill. According to the solid waste composition of the park, $86 \%$ solid waste (garden waste and general waste) for landfill disposal, and the rest of $14 \%$ for recycling (25\% plastics, $48 \%$ glass, $16.7 \%$ paper, and $9 \%$ aluminium) were considered.

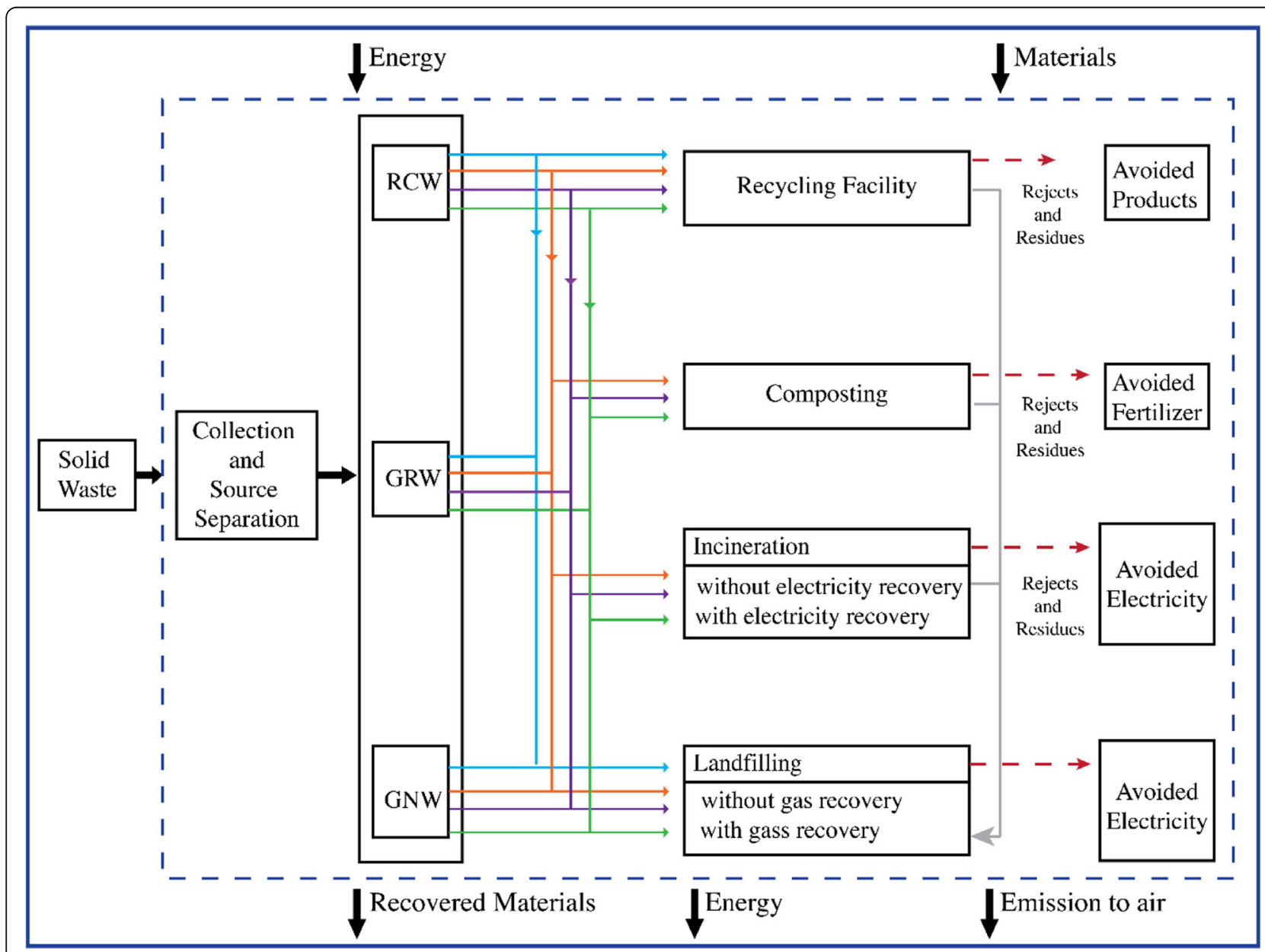

S1 $14 \%$ recycling, and $86 \%$ landfilling:

S2 $18 \%$ recycling, $5.8 \%$ composting, $2 \%$ incineration, and landfilling;

S3 $18 \%$ recycling, $30 \%$ composting, $30 \%$ incineration, and landfilling;

$5430 \%$ recycling, $100 \%$ composting of compostables, $100 \%$ incineration of combustibles (with energy recovery), and landfilling (with energy recovery);

Fig. 1 System boundary of the life cycle SWM system. Remarks: RCW, recyclable waste; GRW, green waste; GNW, general waste 
S2 (scenario 2) represents the current MSW management practice according to the State of Pollution Report 2015, Thailand [1]. S2 considers $18 \%$ of solid waste being sent for recycling, $5.8 \%$ for composting ( $21 \%$ from recycled waste, $2 \%$ from other residual organic and garden waste), $2 \%$ for waste to energy incineration plant, and the rest from general, residual, and green waste to a conventional landfill.

S3 (Scenario 3) represents a combination of an increased ratio of composting (30\%), and incineration (30\%). About $30 \%$ of the organic wastes are sent to a composting plant, while $30 \%$ of recycling rejects and combustibles are sent to incineration plants. The remaining waste and the residuals from composting and incineration are sent to a conventional landfill.

The national policy plan target is to increase recycling up to $30 \%$ and to achieve $100 \%$ proper SWM by 2030 . S4 (scenario 4), based on the national policy plan, Thailand for 2017-2030 [24], considered 30\% recycling of generated waste (including 100\% recycling of dry recyclables), $100 \%$ composting of organic waste and incineration of combustibles, and the use of proper sanitary landfill management (with 50\% gas collection) for the rest of the solid waste and residues.

\section{Impact coverage}

Climate change is an urgent global environmental issue with increasing significance [25]. Climate change has been recognized as one of the good representatives for the environmental impact of SWM [3]. Kaza et al. [4] stated that more than 80 countries have identified SWM as an intervention area in mitigation and adaption to climate change under the United Nations Framework Convention on Climate Change Agreement. Several studies have shown a significant reduction of GHG emissions through attempts to formalize waste management [4, 26]. Therefore, climate change in terms of GWP is considered as the only impact coverage in this study.

\section{Life cycle inventory}

Data for the life cycle inventory were gathered from various primary and secondary sources including reports, literature, and the Ecoinvent 3 databases as detailed below. Also, all the assumptions made are summarized in Table 2.

\section{Reference flow characterization}

A static MFA approach was applied and the freeware STAN 2.6, developed at the Vienna University of

Table 2 Assumptions used in MFA and LCA

\begin{tabular}{|c|c|c|c|}
\hline \multicolumn{3}{|l|}{ Assumption } & \multirow{2}{*}{ Ref. } \\
\hline Goal and scope & & $\begin{array}{l}\text { - Environmental impacts from upstream life cycle stages before the } \\
\text { SW collection were excluded } \\
\text { - Environmental impacts of the infrastructures, capital goods, and } \\
\text { wastewater treatment from the treatment plants were also excluded } \\
\text { - The collection and the source separation assumed to have no material } \\
\text { and energy consumption }\end{array}$ & \\
\hline \multirow[t]{7}{*}{$\mathrm{LCl}$} & \multirow[t]{2}{*}{ MFA } & $\begin{array}{l}\text { Considered transfer coefficients are recycling process }(25.5 \% \text { - } \\
\text { plastic, } 11 \% \text {-paper, } 0 \% \text {-glass, } 16.5 \% \text {-aluminum), 35\%-composting } \\
\text { process, and } 17 \% \text {-incineration process }\end{array}$ & {$[24,27,28]$} \\
\hline & & - Emissions of biogenic $\mathrm{CO}_{2}$ were assumed to be neutral & {$[27,29]$} \\
\hline & Landfilling with gas recovery & - The efficiency of the landfilling system with gas recovery is 50\% & {$[27,29]$} \\
\hline & Recycling system & $\begin{array}{l}\text { - Secondary products produced from the recycling process } \\
\text { replace the production of alternative products. The potential } \\
\text { avoidance of primary products (90\%-plastic, 95\%-glass, } \\
\text { 90\%-paper, } 75 \% \text {-aluminum) }\end{array}$ & {$[30,31]$} \\
\hline & Composting process & $\begin{array}{l}\text { - Compost produced from the composting process replaces the } \\
\text { chemical fertilizers in } \mathrm{S} 4 \text {. The potential avoidance of chemical } \\
\text { fertilizer usage is } 7.1 \mathrm{~kg} \mathrm{~N}, 4.1 \mathrm{~kg} \mathrm{P}_{2} \mathrm{O}_{5}, 5.4 \mathrm{~kg} \mathrm{~K}_{2} \mathrm{O} \mathrm{t}^{-1} \text { of compost. }\end{array}$ & \multirow[t]{3}{*}[30,31]{} \\
\hline & Incineration process & $\begin{array}{l}\text { - The electricity recovering efficiency at the incineration plant for } \\
\text { S2 and S3 is } 8 \% \text { and for S4 20\% } \\
\text { - Electricity produced from incineration displaces an equivalent } \\
\text { amount of electricity generated }\end{array}$ & \\
\hline & Transportation & $\begin{array}{l}\text { - Transport distances } \\
50 \mathrm{~km} \text { (to landfill) } \\
10 \mathrm{~km} \text { (to composting plant) } \\
100 \mathrm{~km} \text { (to incineration plant) } \\
50 \mathrm{~km} \text { (to recyclable waste collection plant) } \\
\text { - the process "Transport, municipal waste collection, } 21 \mathrm{t} \text { lorry and freight, } \\
\text { lorry" for waste transportation to the landfill site, composting plant, and } \\
\text { incineration plant } \\
\text { - the process "Transport, freight, lorry, unspecified" was selected for the } \\
\text { transportation of recyclable waste to the treatment facility }\end{array}$ & \\
\hline
\end{tabular}


Technology, was used to set up the mass flows of the different scenarios [19]. The input (import flows) into the waste management system is the solid waste generated and collected in the CUCP in 2018. The outputs (export flows) are the secondary products and emissions to the environment. Transfer coefficients describe the partitioning of a material or a substance in a process [32]. Therefore, outputs were calculated mainly using transfer coefficients which were derived based on our data and by the literature search. Landfills are final sinks where all the remaining solid waste arrives finally for long term storage. The waste that has not been properly treated and also residues from other treatment facilities end up in landfills. Therefore, they are the only stocks used in this system.

\section{Transportation and electricity}

After the collection of waste generated at the CUCP, segregated wastes were transported into treatment plants and the landfill. Transportation and pre-treatment operations contribute to a part of the environmental impacts causing global warming. Transport distances between the park to the landfill site, a composting plant, incineration plant, and the recyclable waste collection plants were considered as 50, 10, 100, and $50 \mathrm{~km}$, respectively. The unit process for the transportation (SimaPro 8.5.0) was selected as the process 'Transport, municipal waste collection, 21 metric ton lorry' for waste transportation to the landfill site, composting plant, and incineration plant while 'Transport, freight, lorry, unspecified' was selected for the transport of recyclable waste to the treatment facility as they are transported by local collectors. All electricity requirements are derived from Thailand's national electricity records and used as medium voltage under the electricity country mix as reported in SimaPro 8.5.0.

\section{Landfilling}

Landfilling is the most common municipal waste disposal method in Thailand. A conventional landfilling system without energy recovery was considered for S1 to S3, while in $\mathrm{S} 4$ a landfilling system with $50 \% \mathrm{CH}_{4}$ recovery was considered. Among landfill gasses, $\mathrm{CH}_{4}$ contributes to GWP potential whereas $\mathrm{CO}_{2}$ is of biogenic origin [33]. $\mathrm{CH}_{4}$ emissions from uncontrolled landfilling have been considered as the third largest anthropogenic $\mathrm{CH}_{4}$ source [34]. In this study, $\mathrm{CH}_{4}$ generated in the landfilling system is estimated based on the IPCC (Intergovernmental Panel on climate change), 2006 default method [30, 33] using Eq. (1).

$$
\begin{aligned}
& \mathrm{CH}_{4 . \text { emission }}\left(\mathrm{Gg} \mathrm{yr}^{-1}\right) \\
& \quad=\left(\mathrm{MSW}_{\mathrm{T}} \times \mathrm{MSW}_{\mathrm{F}} \times \mathrm{MCF} \times \mathrm{DOC} \times \mathrm{DOC}_{\mathrm{F}} \times \mathrm{F} \times \frac{16}{12}-\mathrm{R}\right) \times(1-\mathrm{OX})
\end{aligned}
$$

where $\mathrm{MSW}_{\mathrm{T}}$ is the total solid waste generated $(\mathrm{Gg}$ $\left.\mathrm{yr}^{-1}\right), \mathrm{MSW}_{\mathrm{F}}$ is the fraction of solid waste disposed, MCF is the methane correction factor, DOC is the degradable organic carbon, $\mathrm{DOC}_{\mathrm{F}}$ is the fraction of DOC factor, $\mathrm{F}$ is the $\mathrm{CH}_{4}$ fraction, $\mathrm{R}$ is the $\mathrm{CH}_{4}$ recovered $\left(\mathrm{Gg} \mathrm{yr}^{-1}\right)$, and $\mathrm{OX}$ is the oxidation factor.

The efficiency of the landfilling system with gas recovery was assumed to be 50\% [27] in S4. Details of energy and material inputs for the landfilling system are presented in Table 3.

\section{Recycling}

A recycling system for mixed plastic, mixed container glass, paper, and aluminium/steel cans was considered. GHG emissions from each type of recyclable and virgin resources were calculated based on the country-specific information in Thailand as reported by [31] and Ecoinvent 3 databases [36]. GHG avoidance potential for each recyclable material was considered and used since the amount of recovered materials is equal to the amount of potential avoidance of virgin resources [31]. Table 3 presents the energy and material inputs for the wastes recycling facility. The information regarding the avoided virgin materials due to waste recycling is presented in Table 4.

\section{Composting}

Since the majority of the waste collected in the park is organic and due to Chulalongkorn University's recent aspiration towards composting of organic waste generated at the University, this treatment method was considered for S2, S3, and S4. The data, such as diesel and electricity requirements during the operation phase of composting, were taken as the windrow composting of the commingled waste facility in Wiang Fang municipality, Northern Thailand as reported by Chanchampee [35]. Emissions during the operation were estimated according to IPCC, 2006 default emission factors [33]. $\mathrm{CH}_{4}$ formed due to anaerobic degradation of waste was taken into account, while $\mathrm{CO}_{2}$ was ignored since such $\mathrm{CO}_{2}$ has biogenic origin [33]. The details of inputs of the inventory of the composting system are shown in Table 3. The potential avoidance of chemical fertilizer usage (7.1 kg N, $4.1 \mathrm{~kg} \mathrm{P}_{2} \mathrm{O}_{5}, 5.4 \mathrm{~kg} \mathrm{~K}_{2} \mathrm{O} \mathrm{t}^{-1}$ of compost), and respective emissions were considered for $\mathrm{S} 4$ [31].

\section{Incineration}

Incineration is considered to be an effective treatment method that can decrease the volume (90\%) and the mass $(75 \%)$ of waste to be landfilled [37]. This waste treatment generates global warming-related emissions, such as $\mathrm{CO}_{2}, \mathrm{~N}_{2} \mathrm{O}$, and $\mathrm{NOx}$ [33]. Incineration was used for S2, S3, and S4. The inventories of incineration for operation including total fossil fuel and electricity 
Table 3 Inventories for landfilling, recycling, composting, and incineration facilities

\begin{tabular}{|c|c|c|c|}
\hline Resources Input & Value & Unit & Ref. \\
\hline \multicolumn{4}{|l|}{ Landfilling } \\
\hline Electricity & 2.5 & $\mathrm{kWh} \mathrm{t}{ }^{-1}$ & [35] \\
\hline Electricity demand for gas collection & 0.2 & $\mathrm{kWh} \mathrm{m}^{-3}$ landfill gas & [35] \\
\hline Diesel & 0.6 & $L t^{-1}$ & [35] \\
\hline \multicolumn{4}{|l|}{ Recycling } \\
\hline Plastics & & & [36] \\
\hline Electricity & 544.2 & $\mathrm{kWh} \mathrm{t}{ }^{-1}$ & \\
\hline Glass & & & [31] \\
\hline Coal brown & 2.1 & $\mathrm{~kg} \mathrm{t}^{-1}$ & \\
\hline Natural gas & 20.9 & $m^{3} t^{-1}$ & \\
\hline Coal & 10.3 & $\mathrm{~kg} \mathrm{t}^{-1}$ & \\
\hline Limestone & 4.5 & $\mathrm{~kg} \mathrm{t}^{-1}$ & \\
\hline Sodium chloride & 0.6 & $\mathrm{~kg} \mathrm{t}^{-1}$ & \\
\hline Paper & & & [31] \\
\hline Electricity & 436.7 & $\mathrm{kWh} \mathrm{t}{ }^{-1}$ & \\
\hline Kaolin & 53.5 & $\mathrm{~kg} \mathrm{t}^{-1}$ & \\
\hline Aluminium sulphate powder & 8.6 & $\mathrm{~kg} \mathrm{t}^{-1}$ & \\
\hline Aluminium & & & [31] \\
\hline Electricity & 89.1 & $\mathrm{kWh} \mathrm{t}{ }^{-1}$ & \\
\hline Total Thermal Energy & 3328.6 & MJ & \\
\hline Bauxite & 0.1 & $\mathrm{~kg} \mathrm{t}^{-1}$ & \\
\hline Cast ingot & 700 & $\mathrm{~kg} \mathrm{t}^{-1}$ & \\
\hline \multicolumn{4}{|l|}{ Composting } \\
\hline Electricity & 5.6 & $\mathrm{kWh} \mathrm{t} \mathrm{t}^{-1}$ & Wiang Fang plant, Chiang Rai, Thailand [35] \\
\hline Diesel & 1.3 & $L t^{-1}$ & \\
\hline \multicolumn{4}{|l|}{ Incineration } \\
\hline Electricity & 86.4 & $\mathrm{kWh} \mathrm{t}{ }^{-1}$ & Phuket incineration plant [37] \\
\hline Diesel & 0.4 & $\mathrm{~kg} \mathrm{t}^{-1}$ & \\
\hline $\mathrm{NaOH}$ & 0.03 & $\mathrm{~kg} \mathrm{t}^{-1}$ & \\
\hline Lime & 6.5 & $\mathrm{~kg} \mathrm{t}^{-1}$ & \\
\hline Water & 356 & $\mathrm{~kg} \mathrm{t}^{-1}$ & \\
\hline
\end{tabular}

Table 4 Substitution options for recycling

\begin{tabular}{llll}
\hline Type of recyclables & Avoided production & Ratio (\%) & Ref. \\
\hline Mixed plastic waste & Polyethylene terephthalate & 90 & {$[31]$} \\
Mixed glass waste & White glass & 36 & {$[31]$} \\
& Green glass & 57 & \\
& Brown glass & 02 & \\
Mixed paper waste & Kraft paper & 90 & [31] \\
Aluminium waste & Aluminium & 75 & {$[31]$} \\
\hline
\end{tabular}

consumption and other material used were obtained from the Phuket incineration plant, Thailand as reported by Menikpura et al. [38] and Chanchampee [35], and are presented in Table 3. According to Menikpura et al. [38], the average electricity production potential in the Phuket incineration plant is 144 $\mathrm{kWh} \mathrm{t}^{-1}$ combustibles, while the operation activities require $60 \%$ of the produced electricity. The electricity recovering efficiency at the incineration plant for S2 and S3 was considered as $8 \%$, while $20 \%$ is considered for S4. However, only the combustion $\mathrm{CO}_{2}$ emissions from the fossil-based waste were considered and GHG emissions were estimated according to IPCC, 2006 Tier 2 approach [33] using Eq. (2). 


$$
\mathrm{CE}=\sum_{\mathrm{i}}\left(\mathrm{SW}_{\mathrm{i}} \times \mathrm{dm}_{\mathrm{i}} \times \mathrm{CF}_{\mathrm{i}} \times \mathrm{FCF}_{\mathrm{i}} \times \mathrm{OF}_{\mathrm{i}}\right) \times \frac{44}{12}
$$

where $\mathrm{CE}$ is the combustion emissions $\left(\mathrm{kg} \mathrm{CO}_{2} \mathrm{t}^{-1}\right.$ of waste), $\mathrm{SW}_{\mathrm{i}}$ is the total amount of solid waste type $\mathrm{i}$ (wet weight) incinerated ( $\mathrm{kg} \mathrm{t}^{-1}$ of waste), $\mathrm{dm}_{\mathrm{i}}$ is the dry matter content in the waste incinerated, $\mathrm{CF}_{\mathrm{i}}$ is the fraction of carbon in the dry matter, $\mathrm{FCF}_{\mathrm{i}}$ is the fraction of fossil carbon in the total carbon, $\mathrm{OF}_{\mathrm{i}}$ is the oxidation factor, $44 / 12$ is the conversion factor from $\mathrm{C}$ to $\mathrm{CO}_{2}$, and subscript $i$ is the type of fossil-based waste incinerated.

\section{Life cycle impact assessment}

The life cycle impact assessment was performed in terms of GWP using the IPCC 2013 GWP 100a method [25]. The considered GHGs were $\mathrm{CO}_{2}$-fossil, $\mathrm{CH}_{4}$, and $\mathrm{N}_{2} \mathrm{O}$. GWP is expressed as $\mathrm{kg} \mathrm{CO}_{2} \mathrm{e}$.

\section{Sensitivity analysis}

The sensitivity of the results of the impact of GWP of considered SWM systems was investigated. The sensitivity analysis 1 was performed in S4, varying the electricity recovery efficiency $(8-30 \%)$ of the incineration plant. This evaluates how results are sensitive to variations in input data and modeling choices [39]. The sensitivity analysis 2 was performed by changing the impact assessment method for S1-4. IPCC 2013 method [25] measures only the impact regarding climate change as a mid-point indicator while the ReCiPe method measures a broader set of environmental impacts [40]. ReCiPe method is considered as one of the most popular and widely used methods to investigate GWP. It was developed integrating two impact assessment methods; the problem-oriented approach and the damage-oriented approach [41]. Therefore, the ReCiPe Midpoint (H) method was used to check the robustness of the results obtained from the IPCC 2013 GWP 100a. The GWP is sensitive to the selected time horizon. Thus, two fixed time horizons were selected ( 20 and $100 \mathrm{yr}$ ) as the GWP of 20 -yr time horizon is higher than that of the $100-\mathrm{yr}$ time horizon.

\section{Results and discussion \\ Characterization of solid waste}

The total input of solid waste into the investigated system is $112.5 \mathrm{t}$ in 2018. Figure 2 presents the generated solid waste composition in the CUCP. Garden waste is the major constituent of the organic waste generated in the park representing $81 \%$ of the total waste. The rest includes recyclable waste: $7 \%$ glass, $4 \%$ plastic, $1 \%$ aluminum/steel, and $2 \%$ potentially recyclable paper waste. The general waste (5\%) includes food waste, and hygiene products, such as diapers, clothes, and other wastes.

\section{MFA as a base for decision making}

Since the overall set of data in MFA allows comparing the scenarios and quantifying the wastes loaded to each treatment method, MFA was developed for each of the considered scenarios. The MFA on the level of goods and the details of inputs, outputs, and stocks in ton per year for S1, S2, S3, and S4 are presented in Fig. 3a, b, c, and $\mathrm{d}$, respectively. The treatment methods, substitution options, and the quantity of solid waste distributed in different scenarios are also presented in Tables 5, 6, 7.

Figure 3a presents the mass balances of waste management in S1. $112.5 \mathrm{t} \mathrm{yr}^{-1}$ of solid waste generated in the

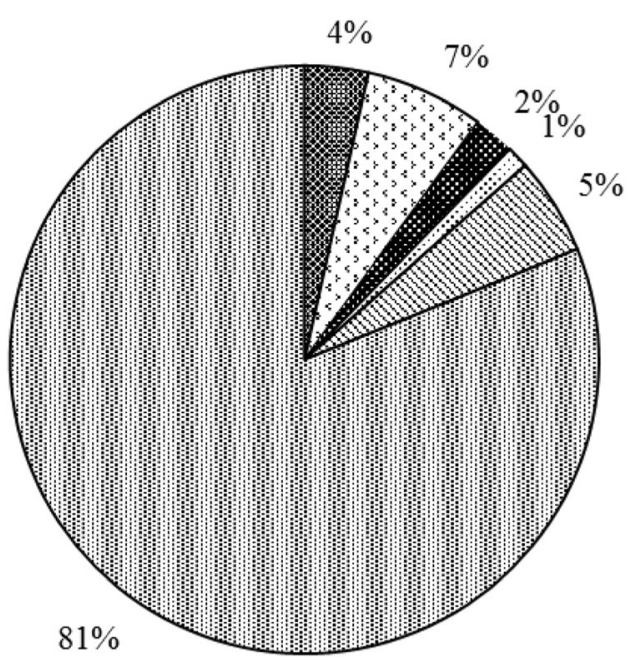

Plastic

๒Glass

9aper

ĐAluminium

\&General waste

图Biomass waste (plants and debris)

Fig. 2 Composition of solid waste in CUCP in 2018 


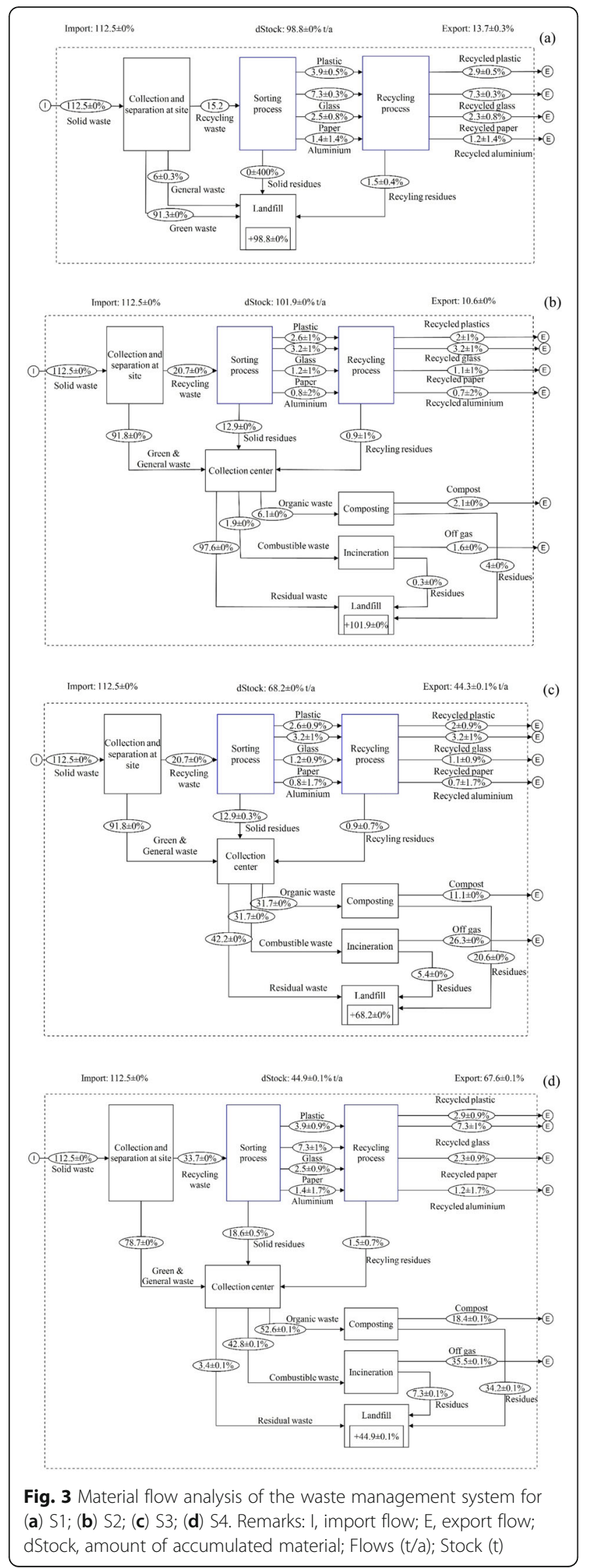

park were collected from the municipality, $86 \%$ of which were transported to a landfill, while the rest as recyclable wastes $(13.5 \%)$ were transported to recycling facilities. The dominant primary waste stream of the park is green/garden waste $\left(91.3 \mathrm{t} \mathrm{yr}^{-1}\right)$. The model suggests that $13.7 \mathrm{t} \mathrm{yr}^{-1}$ treated recyclable wastes can be directly used as substitutions of respective raw materials if $100 \%$ of the recyclable wastes were properly treated.

Compared to S1, S2 was found to have a decreased ratio of recycling and an increase in the amount of solid waste transported to a landfill as a result of residuals from composting and incineration facilities. As can be seen in Fig. $3 \mathrm{~b}$ and Table 5, more than $90 \%$ of the carbon ends up in a landfill in S2. This increased amount of carbon increases the amount of landfill gas, contributing to global warming. Also, this decreases the potential benefits of the ability of material and/or energy recovery from certain wastes. Therefore, it is clear that the current municipal waste management system in Thailand should be improved in a way that decreases the volume of a landfill and increases the ratio of material and energy recovery from wastes.

The combination of an increased ratio of wastes going to composting and incineration facilities in scenario S3 and S4 decreases the amounts of waste that end up in a landfill (Fig. 3c, and d). Landfill diversion ratios of S3 and S4 are found to be 63 and $98 \%$, respectively. Composting of organic waste and incineration of combustibles in S3 and S4 decreases the amount of direct solid waste disposal (63.4 and $95.4 \mathrm{t} \mathrm{yr}^{-1}$, respectively) over the landfill, decreasing the potential long-term emissions to the environment. Besides, enhanced composting and incineration approaches, together with the considered increased energy and material recovery ratios of S4, balance the possible environmental burdens caused in S2 and S3.

Two different ratios of recycling were considered in the recycling system. Figure 4 indicates the mass balances of recycling systems. In S1 and S4, 100\% of collected recyclables were considered recycled despite the current waste management system in Thailand, while S2 and S3 followed the current system as reported by PCD, 2016 [1] as shown in Table 7. The recyclables are manually sorted and weighted at the site of the waste collection before transported into the treatment facility. Therefore, it was assumed that the residues are negligible at the sorting facility. Similar to the recycling ratio, the recycling processes have different efficiencies. Therefore, recycling residues amounts in waste flow are different [28]. Transfer coefficients for the recycling processes of plastic, glass, paper, and aluminium were taken from Arena and Di Gregorio [28] and the respective ratios of recycling residues are presented in Table 7. 
Table 5 Comparison of MFA indicator results for different scenarios

\begin{tabular}{|c|c|c|c|c|c|}
\hline \multirow[t]{2}{*}{ SWM system } & \multirow[t]{2}{*}{ Description $^{a}$} & \multicolumn{4}{|c|}{$\begin{array}{l}\text { Quantity of solid } \\
\text { waste treated }\end{array}$} \\
\hline & & S1 & $\mathrm{S} 2$ & S3 & S4 \\
\hline Landfilling $\left(\mathrm{t} \mathrm{yr}^{-1}\right)$ & & 98.8 & 101.9 & 68.2 & - \\
\hline Landfilling with energy recovery $\left(\mathrm{tyr}^{-1}\right.$ ) & & - & - & - & 44.8 \\
\hline Recycling $\left(\right.$ t yr $\left.^{-1}\right)$ & & 15.2 & 7.8 & 7.8 & 15.2 \\
\hline Composting $\left(\mathrm{t} \mathrm{yr}^{-1}\right)$ & & 0 & 6.1 & 31.7 & 52.6 \\
\hline Incineration with energy recovery $\left(\mathrm{t} \mathrm{yr}^{-1}\right)$ & & 0 & 2.0 & 31.7 & 42.8 \\
\hline Landfill ratio (\%) & $\begin{array}{l}\text { Total tons of SW sent directly to the landfill plus tons of rejected } \\
\text { from other facilities divided by total tons of SW }\end{array}$ & 87.8 & 90.6 & 60.6 & 39.8 \\
\hline Recycling/composting ratio (\%) & $\begin{array}{l}\text { Sum of tons of SW sent for recycling and composting divided by } \\
\text { the total tons of SW }\end{array}$ & 13.5 & 12.4 & 35.0 & 60.3 \\
\hline Landfill diversion ratio (\%) & Sum of tons of SW not sent directly to landfill divided by total tons of SW & 13.5 & 14.3 & 63.3 & 98.3 \\
\hline
\end{tabular}

${ }^{\mathrm{a}}$ Description and the calculations are according to Turner et al. [3]

It was assumed that the efficiency of the composting facility is $35 \%$, and $0.35 \mathrm{t}$ of compost can be produced from $1 \mathrm{t}$ of organic waste input. In addition, it was considered that incineration of $1 \mathrm{t}$ of combustible wastes generated $0.17 \mathrm{t}$ of residues which should end up in a landfill [35].

Landfills became a final sink for solid waste in all S1, S2, S3, and S4 scenarios. A final sink holds a substance for a very long period or destroys substances completely [42]. Increased ratio of alternative waste treatments in S3 and S4 decreases the amount of un-treated and residual waste, minimizing the use of a landfill. It was found that, from S2 to S3 and S4, the landfilling ratio decreased from 90 to 60 and 39\%, while the landfill diversion ratio increased from 14 to 63 and $98 \%$, respectively, due to the increased ratio of recycling/composting and incineration (Table 5). This provides various benefits to the waste management system.

Carbon is an indicator of resource potentials, such as energy and biomass. It is also considered an environmental hazard due to potential GHG emissions, and persistent toxic substances $[28,43]$. Since the major portion of the waste is organic, composting facilitates the utilization of waste carbon in the form of compost. The increasing ratio of composting from $5.4 \%$ in S2 to > 50\% in S3 and S4 significantly decreases the required volume of landfills. Also, due to an increased ratio of incineration, more than half of the increased amount of waste transported into the treatment plant is wood waste from the garden in S3 and S4. Therefore, the emissions are non-fossil in origin and do not account for the GWP. Even though the waste composition affects the efficiency of incineration due to low heating values in the presence of high moisture and ash content, this still decreases the amount of organic carbon loaded to the landfill, leaving only the inorganic carbon from the incineration residues to be loaded into the landfill. The results of MFA indicate that a significant reduction of the landfill loading of solid waste can be achieved by effective source separation and considering the potential integrated approaches: such as recycling of dry recyclable wastes, composting of organic waste, and incineration of combustibles.

Table 6 Substitution options for waste treatment at different scenarios

\begin{tabular}{|c|c|c|c|c|c|c|c|}
\hline \multirow{2}{*}{$\begin{array}{l}\text { Solid waste management } \\
\text { system }\end{array}$} & \multirow[t]{2}{*}{ Avoided processes } & & \multirow{2}{*}{$\begin{array}{l}\text { Replacement } \\
\text { ratio (\%) }\end{array}$} & \multicolumn{4}{|c|}{ Considered scenario } \\
\hline & & & & S1 & $\mathrm{S} 2$ & S3 & S4 \\
\hline Landfilling & Gas collection & $\mathrm{CH}_{4}$ & 50 & - & - & - & $\checkmark$ \\
\hline \multirow[t]{4}{*}{ Recycling } & Virgin material production & Plastic & 90 & & & & \\
\hline & & Glass & 95 & & & & \\
\hline & & Paper & 90 & & & & \\
\hline & & Aluminum & 75 & $\checkmark$ & $\checkmark$ & $\checkmark$ & $\checkmark$ \\
\hline \multirow[t]{4}{*}{ Composting } & Chemical fertilizer production & Fertilizer & & & & & \\
\hline & & $7.1 \mathrm{~kg} \mathrm{~N}$ & 0.8 & & & & \\
\hline & & $4.1 \mathrm{~kg} \mathrm{P}_{2} \mathrm{O}_{5}$ & 0.5 & - & - & - & $\checkmark$ \\
\hline & & $5.4 \mathrm{~kg} \mathrm{~K}{ }_{2} \mathrm{O}$ & 0.6 & & & & \\
\hline \multirow[t]{2}{*}{ Incineration } & Electricity recovery & Electricity & 8 & $\checkmark$ & $\checkmark$ & $\checkmark$ & - \\
\hline & & & 20 & - & - & - & $\checkmark$ \\
\hline
\end{tabular}


Table 7 Recycling ratios and transfer coefficients of the SWM systems

\begin{tabular}{|c|c|c|c|c|c|c|c|c|}
\hline & Plastic & Glass & Paper & Aluminium/steel & Organic waste & Combustible waste & Reference & $\begin{array}{l}\text { Considered } \\
\text { scenarios }\end{array}$ \\
\hline Recycling ratio 1 (\%) & 100 & 100 & 100 & 100 & - & - & $\begin{array}{l}\text { Personal communication } \\
\text { with park service staff }\end{array}$ & $\mathrm{S1}, \mathrm{S} 4$ \\
\hline Recycling ratio 2 (\%) & 67 & 43 & 47 & 60 & - & - & [1] & $\mathrm{S} 2, \mathrm{S3}$ \\
\hline \multicolumn{9}{|l|}{ Transfer coefficients } \\
\hline Recycling residues (\%) & 25.5 & 0.0 & 11.0 & 16.5 & - & - & [28] & S1-S4 \\
\hline Compost production (\%) & - & - & - & - & 35 & & {$[35]$} & S2-S4 \\
\hline Incineration residue (\%) & - & - & - & - & & 17 & [35] & S2-S4 \\
\hline
\end{tabular}
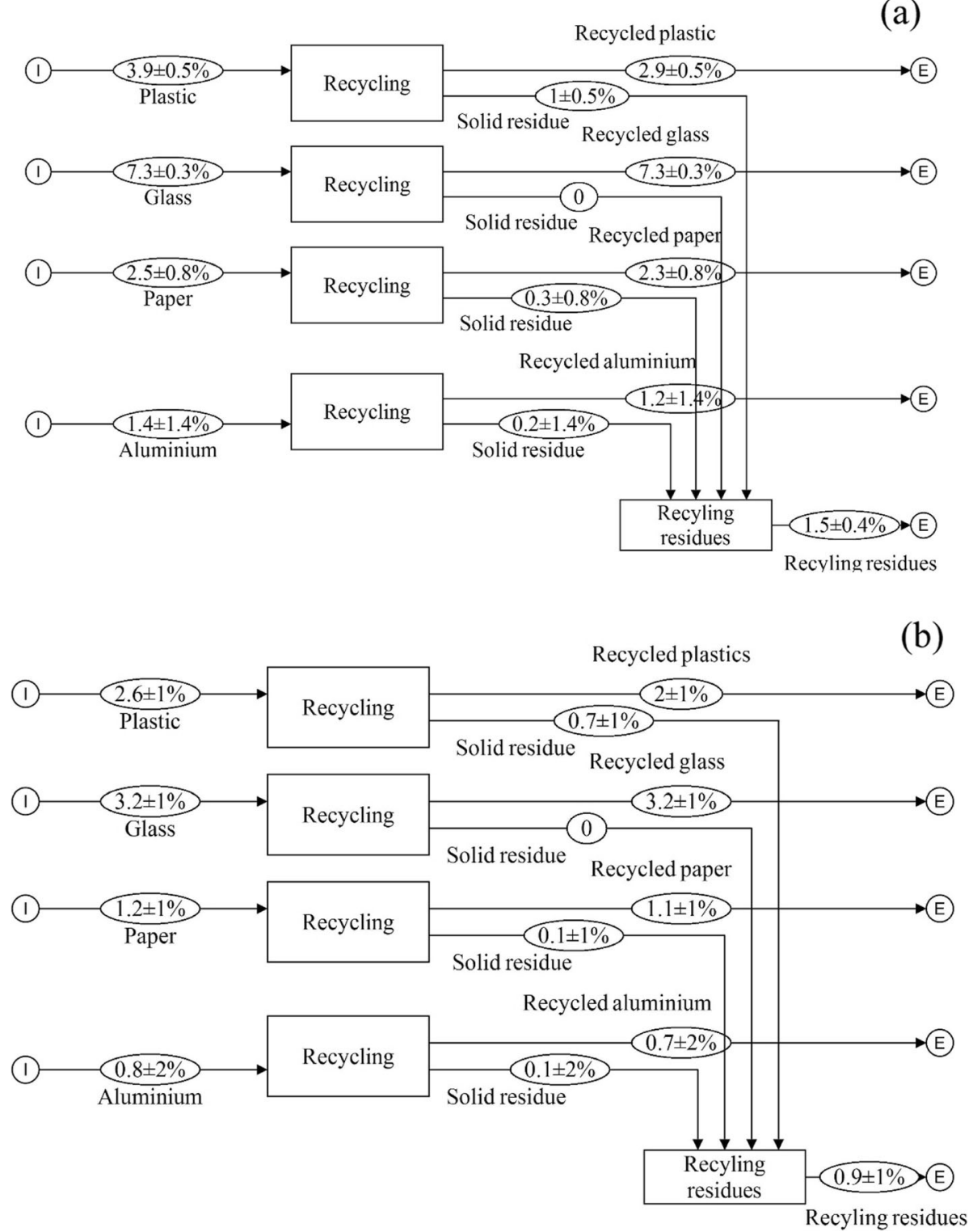

Fig. 4 Material flow analysis of the recycling system; (a), considered for S1 and S4; (b), considered for S2 and S3 (I, import flow; E, export flow; Flows (t/a)) 


\section{Life cycle impact assessment}

\section{Global warming potential}

Figure $5 \mathrm{a}$ shows the GWP in terms of total $\mathrm{kg} \mathrm{CO}_{2} \mathrm{e}$ emissions per scenario of waste management in CUCP. All the scenarios considered in the study were found to result in net GHG burdens (environmental loads). S1 resulted in an environmental load of $2.9 \mathrm{E}+05 \mathrm{~kg} \mathrm{CO}_{2} \mathrm{e}$ due to landfill application of waste and $-1.8 \mathrm{E}+04 \mathrm{~kg}$ $\mathrm{CO}_{2} \mathrm{e}$ of environmental saving due to recycling, contributing a net $\mathrm{GHG}$ burden of $2.7 \mathrm{E}+05 \mathrm{~kg} \mathrm{CO} \mathrm{CO}_{2} \mathrm{e}$ S2, which represents the existing waste management practice in Thailand, had its dominant GHG burden contribution in the form of landfilling $(2.5 \mathrm{E}+05 \mathrm{~kg} \mathrm{CO} 2 \mathrm{e})$, while incineration and composting contribute 290 and $100 \mathrm{~kg} \mathrm{CO}_{2} \mathrm{e}$ GWP, respectively. S2 and S3 considered a landfill site without gas collection and a composting facility that is not able to suppress chemical fertilizer usage. Since the energy recovery at the incineration plant ( $8 \%$ energy recovery efficiency) is not sufficient for offsetting the required energy for waste treatment in S2 and S3, GHG benefits of the recycling of dry recyclables $(-1.0 \mathrm{E}+04 \mathrm{~kg}$ $\mathrm{CO}_{2} \mathrm{e}$ ) alone decrease the GWP of S2 and S3, similar to $\mathrm{S} 1$. Increased ratio of composting and incineration to $30 \%$ in S3, decreases the amount of waste directly sent to the landfilling sites. However, S3 still represents environmental loads of $1.6 \mathrm{E}+05,5.0 \mathrm{E}+03$, and $5.3 \mathrm{E}+02 \mathrm{~kg}$ $\mathrm{CO}_{2} \mathrm{e}$, for landfilling, incineration, and composting of solid wastes, respectively, resulting in a net GWP of $1.5 \mathrm{E}+05 \mathrm{~kg} \mathrm{CO}_{2} \mathrm{e}$. Avoided environmental loads due to methane and electricity recovery at the landfilling and incineration facility, and potential replacement of fertilizers due to composting decrease the environmental load of each treatment method considered in S4. However, results show that the considered ratio of gas and electricity recovery could not neutralize the potential environmental loads in the waste management system.

\section{Contribution analysis}

The contribution of process type to GWP in each scenario is presented in Fig. 5b. The contribution of waste transportation, on-site operation, and required intermediate facilities for the GWP was considered.

Results show that the transportation of waste plays a major role in GHG emissions in each waste treatment process in all scenarios. The highest GHG emission in $\mathrm{S} 2, \mathrm{~S} 1$, and $\mathrm{S} 3$ is shown in waste landfilling (the GWP are $6.3 \mathrm{E}+03,6.1 \mathrm{E}+03$, and $4.2 \mathrm{E}+03 \mathrm{~kg} \mathrm{CO}_{2} \mathrm{e}$, respectively), while in $\mathrm{S} 4$ transportation of combustible waste to incineration has the highest environmental burden $(5.3 \mathrm{E}+03 \mathrm{~kg} \mathrm{CO} 2 \mathrm{e})$; this is likely due to the transportation of a large amount of combustible waste for a considerable distance for treatment compared to landfill disposal. Since it was assumed that the source segregated recyclable wastes, such as plastic, glass, paper, and aluminium/steel were directly transported to recycling centers using a freight lorry, and due to less amount of available waste as a result of the recycling, the environmental burden of recycling is less compared to other waste treatment methods. The maximum level of waste separation at the source and point of collection minimizes the environmental burdens. Also, the selection of proper waste transportation methods considering the point of treatment and transfer stations improves the overall sustainability of the SWM.

The GWP of intermediate facilities due to required fossil fuels and combustion of fuels during operations are found to be positive, creating an environmental load for landfilling (S1-3), recycling (S1-4), composting (S24 ), and incineration (S2-4). A surplus of recovered gas in landfilling and electricity during incineration creates net GHG benefit of $-5.7 \mathrm{E}+02$ and $-5.3 \mathrm{E}+03 \mathrm{~kg} \mathrm{CO}_{2} \mathrm{e}$ $\mathrm{FU}^{-1}$, respectively due to intermediate facilities in $\mathrm{S} 4$. Results show the avoided GHG emissions from electricity production (with $8 \%$ efficiency) at S2 and S3 could not even offset the GHG emissions from intermediate facilities. In general, the moisture content of the waste used for incineration in Thailand is high, ranging between 40 and $60 \%$. This requires an excessive amount of fuel to burn wet waste at the incineration plant resulting in more GHG emissions [44]. Therefore, appropriate measures should be taken to increase the energy recovering efficiency in the incineration plant and to reduce the use of other fuels by an improvement of the combustion in various ways. The GWP of intermediate facilities in the waste recycling process was found to be the highest in all the scenarios due to high energy consumption during the treatment. The GHG emissions of landfilling operations were found to result in the highest contribution to the GWP of the waste management systems $(\mathrm{S} 1>\mathrm{S} 2>\mathrm{S} 3>\mathrm{S} 4)$. Since large amounts of organic waste are dumped into a landfill in each scenario, the potential of $\mathrm{CH}_{4}$ produced during waste degradation is significantly high, resulting in its maximum contribution to GWP. However, the GWP of the operation phase of the recycling facility was negative, creating an environmental benefit (Fig. 5b). This is likely due to the high ratio of substitution of virgin material with material recycling. Similar to recycling, composting shows a lower GHG emission potential in the operation phase than transportation and required inputs. The composting facility of $\mathrm{S} 4$ was found to contribute $\mathrm{a}-3.1 \mathrm{E}+01 \mathrm{~kg}$ $\mathrm{CO}_{2} \mathrm{e}$ GHG benefit due to considered avoidance of fertilizer application and an equivalent production of compost. GHG emissions due to the combustion of waste at the incineration facility are found to be $2.5 \mathrm{E}+$ $01,4.2 \mathrm{E}+02$, and $5.3 \mathrm{E}+02 \mathrm{~kg} \mathrm{CO}_{2} \mathrm{e}$ for $\mathrm{S} 2, \mathrm{~S} 3$, and $\mathrm{S} 4$, respectively, in line with the amount of waste considered in combustion in each scenario. However, since only the 


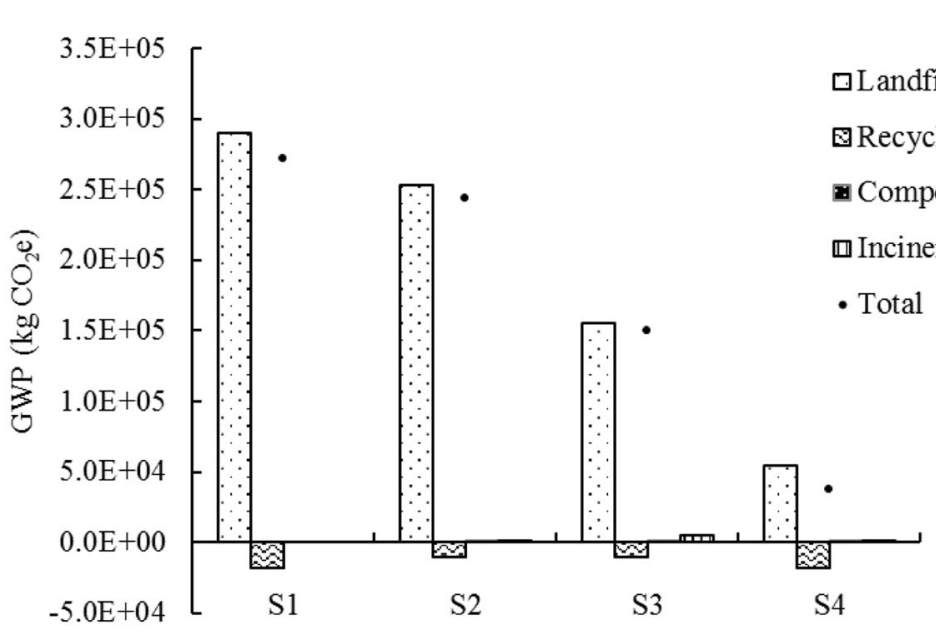

(a)

(b)
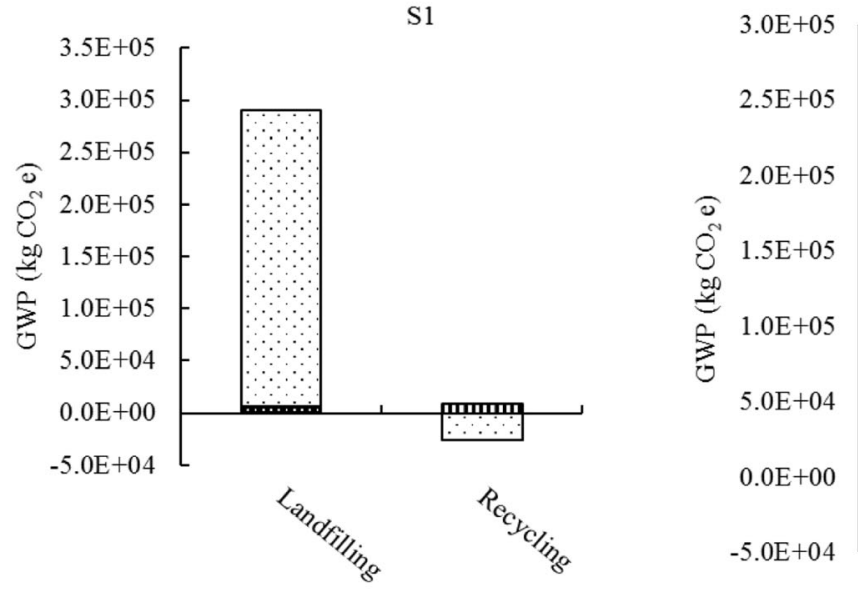

S2
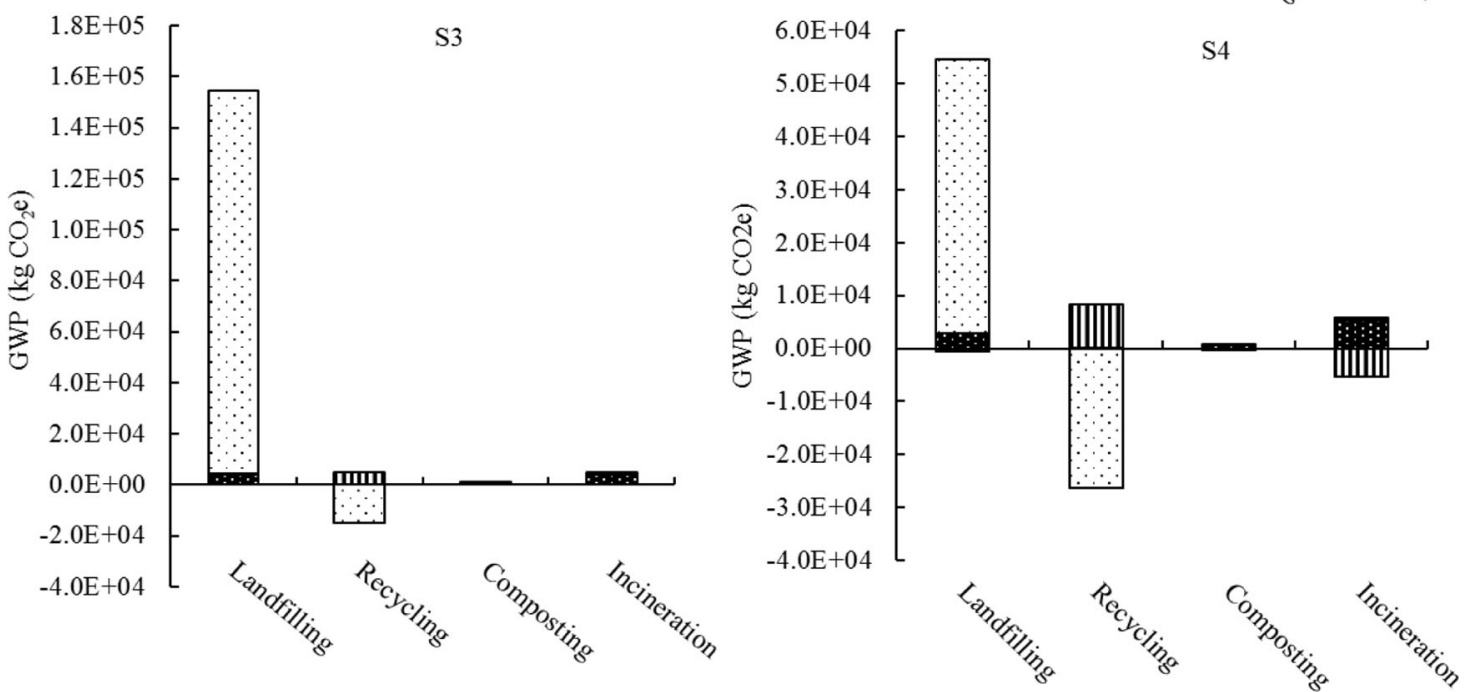

\$ Transport $\mathbf{0}$ Intermediate facilities घOperation

Fig. 5 Life cycle assessment (GWP, $\mathrm{kg} \mathrm{CO}_{2} \mathrm{e} \mathrm{FU}{ }^{-1}$ ) of (a) different scenarios; (b) contribution of process type. Remarks: GWP, global warming potential; FU, functional unit 
emissions of fossil $\mathrm{CO}_{2}$ were considered and the highest fraction of the waste is organic, GHG emissions from waste combustion (operation) of incineration facilities are considerably low.

According to Arena and Di Gregorio [28], an integrated and sustainable waste management system should be developed in a way that minimizes the use of landfills, maximizes the recovery of materials, and maximizes the energy recovery for materials that cannot be recycled, to save both landfill volumes and fossil-fuel resources. The highest portion of generated waste in CUCP is organic with a high volume of tree leaves and barks. Therefore, composting and incineration would be potential waste treatments. Increased ratio of incineration and composting of organic waste certainly decreases the quantity of wastes loaded into landfills. This decreases the GWP of landfill disposal of wastes. Also, potential energy recovery and possible avoidance of chemical fertilizers due to incineration and compost production, respectively, decrease the environmental burdens of GWP of SWM in the park. However, high moisture and ash content, and the low heating value of garden waste limit the amount that can be sent to incineration [8]. In addition, source separation and collection assisted in the improvement of the environmental performance of waste management in the park by decreasing possible extra environmental burdens.

Overall, the results of the study show that environmental loads created by landfilling, composting, and incineration cannot be negated by recycling activities. Even though gas and energy recovery during landfilling and incineration, and possible fertilizer substitution by compost production in composting, decrease the environmental burdens in each scenario, these approaches could not offset the gross GWP of the waste management system and all of them result in a net GHG burden.

In general, landfilling of MSW contributes to the highest GWP as reported in most studies [45]. Similar to that, Liamsanguan and Gheewala [46] reported a higher net GWP of $1.6 \mathrm{E}+03 \mathrm{~kg} \mathrm{CO} 2 \mathrm{e}$ from landfilling (without energy recovery) than compared to $6.5 \mathrm{E}+2 \mathrm{~kg} \mathrm{CO}_{2} \mathrm{e}$ from incineration (with energy recovery) of $1 \mathrm{t}$ of MSW treated in a waste management system in Thailand. Menikpura et al. [38], also reported a net GHG emission of $1.2 \mathrm{E}+3 \mathrm{~kg} \mathrm{CO}$ e from sanitary landfilling (with electricity recovery) while $5.9 \mathrm{E}+2 \mathrm{~kg} \mathrm{CO} \mathrm{CO}_{2} \mathrm{e}$ net $\mathrm{GHG}$ emissions of incineration of $1 \mathrm{t}$ of treated respective waste management in Thailand. These studies also suggest the possibility of the improvement of waste management systems via proper practices.

Results show that MFA facilitates a complete characterization of waste management systems providing an essential base for LCA. An integrated MFA and LCA approach comprehensively evaluate existing and alternative waste management systems and policies. This will support the local authorities in identifying gaps and required improvements in waste management approaches. Thus, this provides a clear path towards sustainable waste management practices. However, waste management directly affects many parts of society and the economy. On the other hand, many socio-economic drivers determine the status of the efficiency of waste management systems. The quantity and the composition of MSW, as well as the efficiency of the appropriate management option, is directly governed by the socioeconomic status $[4,47]$. Therefore, it is required to evaluate environmental impacts considering the social acceptance and awareness along with the economic factors, to ensure the operation of a sustainable waste management system [47]. The implementation of an efficient and environmentally sound integrated waste management system ensures social, economic, and environmental sustainability.

\section{Sensitivity analysis}

Two sensitivity analyses were performed to evaluate the results of the impact of GWP of the considered SWM systems. Figure 6 a illustrates the sensitivity of the GWP of the considered energy recovering efficiency of the incineration plant in S4. The results show that an increase in the ratio of electricity recovery from 8 to 10,20 , and $30 \%$ decreases the GWP due to incineration from 6.7E+ 03 to $5.6 \mathrm{E}+03,4.9 \mathrm{E}+02$, and $-4.7 \mathrm{E}+03 \mathrm{~kg} \mathrm{CO}_{2} \mathrm{e}$, respectively, because the recovery of electricity replaces the same amount of required electricity production from fossil-based generation methods. Increase energy recovery efficiency from 8 to $30 \%$ was found to result in a net decrease of GHG emissions, proving that it is possible for improvements in electricity recovery in incineration plants to increase the environmental benefits of the SWM system.

The results of GWP in each scenario (IPCC 2013 GWP 100a) were compared with IPCC 2013 GWP 20a V1.03, and ReCiPe 2016 Midpoint (H) V1.01 methods. The results are shown in Fig. 6b. The mid-point assessment results of the ReCiPe method tend to be similar to the results found in IPCC 2013 GWP 100a. However, the results of GWP of IPCC 2013 GWP 20a are significantly high as the GWP of GHG at 20-yr time horizon is higher than that of 100-yr time horizon.

\section{Conclusions}

This study compares the SWM options for CUCP, Bangkok, Thailand, in 2018 using an integrated approach based on the MFA and LCA. The current municipal SWM plan in Thailand was assessed in S2, while three alternative systems with different recycling, 


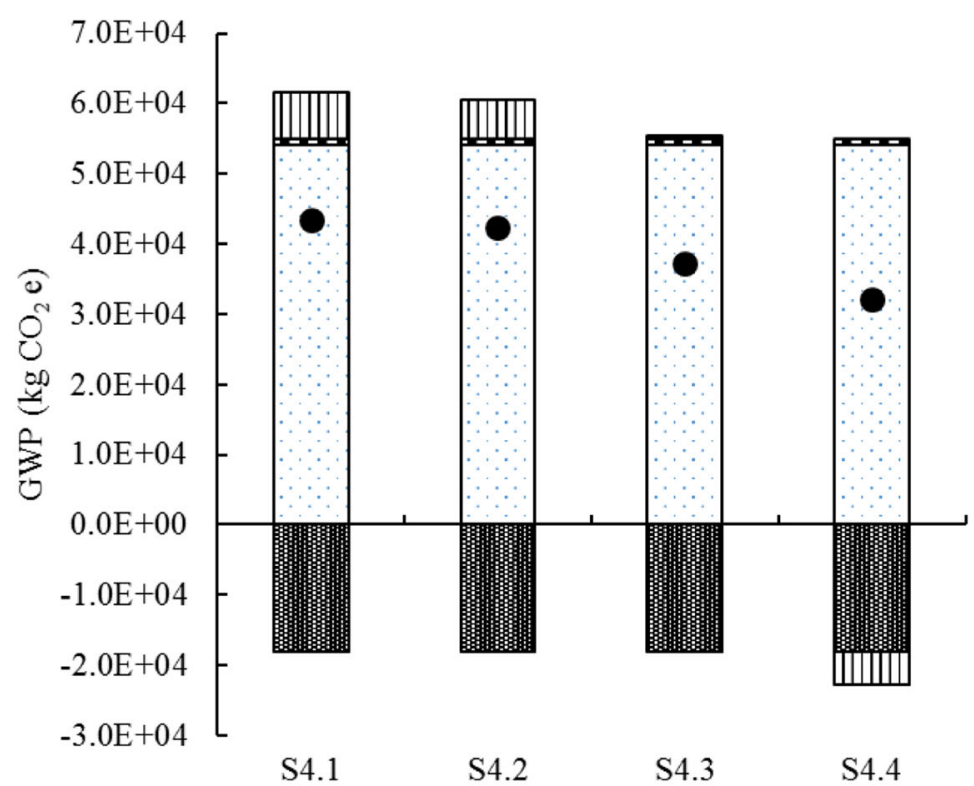

(a)

Scenario 4 with different electricity recovering efficiencies

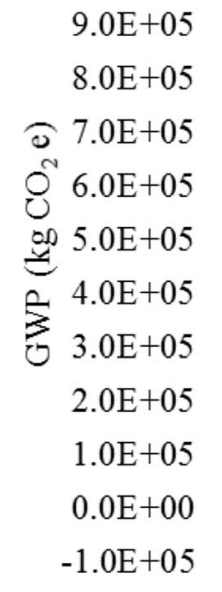

口Landfilling GWP 100a

口Landfilling GWP 20a

๑Landfilling ReCiPe

圈 Recycling GWP 100a

Recycling GWP 20a

目 Recy cling ReCiPe

๑Composting GWP 100a

Q Composting GWP 20a

: Composting ReCiPe

Incineration GWP 100a

m Incineration GWP 20a

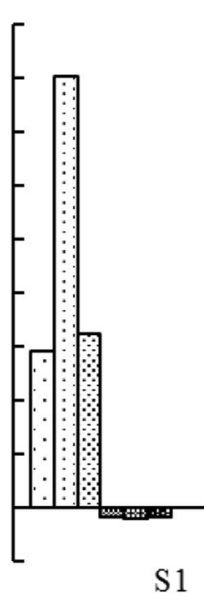

$\mathrm{S} 1$

2.9E+05

$8.0 \mathrm{E}+05$

$3.2 \mathrm{E}+05$

$-1.8 \mathrm{E}+04$

$-2.2 \mathrm{E}+04$

$-1.8 \mathrm{E}+04$

$0.0 \mathrm{E}+00$

$0.0 \mathrm{E}+00$

$0.0 \mathrm{E}+00$

$0.0 \mathrm{E}+00$

$0.0 \mathrm{E}+00$

$0.0 \mathrm{E}+00$

口Incineration ReCiPe

$\mathrm{S} 2$

2.5E+05

$7.0 \mathrm{E}+05$

2. $8 \mathrm{E}+05$

$-1.0 \mathrm{E}+04$

$-1.2 \mathrm{E}+04$

$-1.0 \mathrm{E}+04$

$1.0 \mathrm{E}+02$

1. $1 \mathrm{E}+02$

1. $1 \mathrm{E}+02$

$2.9 \mathrm{E}+02$

$3.0 \mathrm{E}+02$

3. $0 \mathrm{E}+02$

(b)

mIncineration
$\boldsymbol{0}$ Composting

国Recycling

$\square$ Landfilling

Total

Fig. 6 Sensitivity analysis of (a) S4 to electricity recovering efficiency; (b) GWP of S1-4 with different impact methods. Remarks: S4.1, S4.2, S4.3, and S4.4 refers to scenario 4 with 8, 10,20, and 30\% electricity recovering efficiency at incineration plant, respectively; Impact methods, IPCC 2013 GWP 100a V1.03, IPCC 2013 GWP 20a V1.03, and ReCiPe 2016 Midpoint (H) V1.01; GWP, global warming potential 
composting, and incineration ratio were also considered. The majority of the waste generated in the Park is green wastes from garden management (81\%). The results of MFA show that the highest landfill ratio is found in S2, with $101.9 \mathrm{t} \mathrm{yr}^{-1}$ solid wastes. S4 resulted in the highest recycling/composting ratio, energy recovery ratio, and the highest ratio of waste diversion from the landfill. The results of LCA show that $\mathrm{S} 1$ resulted in the highest GWP of $2.9 \mathrm{E}+05 \mathrm{~kg} \mathrm{CO} 2 \mathrm{e}$ followed by $\mathrm{S} 2(2.5 \mathrm{E}+05 \mathrm{~kg}$ $\left.\mathrm{CO}_{2} \mathrm{e}\right), \mathrm{S} 3\left(1.6 \mathrm{E}+05 \mathrm{~kg} \mathrm{CO}_{2} \mathrm{e}\right)$, and $\mathrm{S} 4 \quad(5.4 \mathrm{E}+04 \mathrm{~kg}$ $\left.\mathrm{CO}_{2} \mathrm{e}\right)$. Overall, waste recycling in $\mathrm{S} 1-4(-1.8 \mathrm{E}+04$, and $-1.0 \mathrm{E}+04 \mathrm{~kg} \mathrm{CO}_{2} \mathrm{e}$ ) were found to result in net environmental benefits while composting, incineration, and landfilling were found to result in net environmental burdens. S4 was found to result in the lowest GWP due to an increased ratio of recycling, composting, and incineration, and also due to gas and electricity recovery. The results of the LCA were also found to be sensitive to energy recovering efficiency during incineration. Since all the scenarios considered in the study were found to result in net GHG burdens, the requirement of upgrading the technology with a proper strategy on the waste management system in Thailand can be highlighted.

\section{Supplementary information}

Supplementary information accompanies this paper at https://doi.org/10. 1186/s42834-020-00057-5.

Additional file 1: Figure S1. Waste management practices (a) in Thailand, 2015; (b) global level (adopted from [1, 4]). Figure S2. Location map of the CUCP.

\section{Acknowledgements}

The first author acknowledges the support by the Rachadapisek Sompote Fund for Postdoctoral Fellowship, Chulalongkorn University. The second author is supported by Research Assistantship from the Faculty of Engineering, Chulalongkorn University. The authors thank the Office of Higher Education Commission (OHEC) and the S\&T Postgraduate Education and Research Development Office (PERDO) for their financial support of the research program. This work was conducted under the research program "Control of Residual Hormones and Antimicrobial Agents from Aquacultural and Feedstock Industry" granted by Center of Excellence on Hazardous Substance Management (HSM). This research was also funded by Chulalongkorn University: CU_GR_63_73_21_11. Authors would also like to express our sincere thanks to the Department of Environmental Engineering, Faculty of Engineering, Chulalongkorn University, and the Center of Excellence on Hazardous Substance Management (HSM) for their invaluable supports in terms of funding, facilities, and scientific equipment.

\section{Authors' contributions}

Dr. Indika Thushari is the first author responding to data analysis and manuscript writing. Mr. Juckrit Vicheanteab is the second author who collected and analyzed data under Dr. Indika's supervision. Dr. Dao Janjaroen is the corresponding author who initialized and supervised the whole work. The author(s) read and approved the final manuscript.

\section{Funding}

The first author acknowledges the support by the Rachadapisek Sompote Fund for Postdoctoral Fellowship, Chulalongkorn University. The authors thank the Office of Higher Education Commission (OHEC) and the S\&T Postgraduate Education and Research Development Office (PERDO) for their financial support of the research program.

\section{Availability of data and materials}

Data will not be shared due to privacy and policy of the place from which data was taken.

\section{Competing interests}

The first author acknowledges the support by the Rachadapisek Sompote Fund for Postdoctoral Fellowship, Chulalongkorn University. The authors thank the Office of Higher Education Commission (OHEC) and the S\&T Postgraduate Education and Research Development Office (PERDO) for their financial support of the research program.

Received: 10 September 2019 Accepted: 19 June 2020

Published online: 25 September 2020

\section{References}

1. PCD. Thailand State of pollution report 2015. Bangkok: Pollution Control Department; 2016.

2. Pharino C. Challenges for sustainable solid waste management: lessons from Thailand. Singapore: Springer; 2017.

3. Turner DA, Williams ID, Kemp S. Combined material flow analysis and life cycle assessment as a support tool for solid waste management decision making. J Clean Prod. 2016;129:234-48.

4. Kaza S, Yao LC, Bhada-Tata P, Van Woerden F. What a waste 2.0: a global snapshot of solid waste management to 2050. Washington, DC: World Bank: 2018.

5. UNEP. Waste and climate change: global trends and strategy framework. Osaka: United Nations Environment Programme; 2010.

6. Thaiutsa B, Puangchit L, Kjelgren R, Arunpraparut W. Urban green space, street tree and heritage large tree assessment in Bangkok, Thailand. Urban For Urban Green. 2008;7:219-29.

7. UNDESA. Long-range population projections. New York: United Nations Department for Economic and Social Affairs; 2003.

8. Boldrin A, Andersen JK, Christensen TH. Environmental assessment of garden waste management in the municipality of Aarhus, Denmark. Waste Manage. 2011;31:1560-9.

9. Shi Y, Ge Y, Chang J, Shao HB, Tang YL. Garden waste biomass for renewable and sustainable energy production in China: potential, challenges and development. Renew Sust Energ Rev. 2013;22:432-7.

10. Raud M, Mitt M, Oja T, Olt J, Orupold K, Kikas T. The utilisation potential of urban greening waste: Tartu case study. Urban For Urban Green. 2017;21: 96-101.

11. Andersen JK, Boldrin A, Samuelsson J, Christensen TH, Scheutz C. Quantification of greenhouse gas emissions from windrow composting of garden waste. J Environ Qual. 2010;39:713-24.

12. Allesch A, Brunner PH. Material flow analysis as a tool to improve waste management systems: the case of Austria. Environ Sci Technol. 2017;51:54051.

13. Hadzic A, Voca N, Golubic S. Life-cycle assessment of solid-waste management in city of Zagreb, Croatia. J Mater Cycles Waste. 2018;20:128698.

14. Sevigne-Itoiz E, Gasol CM, Rieradevall J, Gabarrell X. Methodology of supporting decision-making of waste management with material flow analysis (MFA) and consequential life cycle assessment (CLCA): case study of waste paper recycling. J Clean Prod. 2015;105:253-62.

15. Nakem S, Pipatanatornkul J, Papong S, Rodcharoen T, Nithitanakul M, Malakul P. Material flow analysis (MFA) and life cycle assessment (LCA) study for sustainable management of PVC wastes in Thailand. In: Zdravko K, Miloš B, editors. Computer aided chemical engineering. Amsterdam: Elsevier; 2016. p. 1689-94.

16. Padeyanda Y, Jang YC, Ko Y, Yi S. Evaluation of environmental impacts of food waste management by material flow analysis (MFA) and life cycle assessment (LCA). J Mater Cycles Waste. 2016;18:493-508.

17. Haupt M, Kagi T, Hellweg S. Modular life cycle assessment of municipal solid waste management. Waste Manag. 2018;79:815-27.

18. Albert S. editor. Innovative solutions for creating sustainable cities. Newcastle upon Tyne: Cambridge Scholars Publishing; 2019.

19. Cencic O. Nonlinear data reconciliation in material flow analysis with software STAN. Sustain Environ Res. 2016;26:291-8.

20. ISO. ISO 14040:2006. Environmental management - life cycle assessment principles and framework. Geneva: International Organization for Standardization; 2006. 
21. ISO. ISO 14044:2006. Environmental management - life cycle assessment requirements and guidelines. Geneva: International Organization for Standardization; 2006.

22. Ekvall T, Assefa G, Björklund A, Eriksson O, Finnveden G. What life-cycle assessment does and does not do in assessments of waste management. Waste Manag. 2007;27:989-96.

23. Sarto GM. Life cycle assessment of municipal solid waste treatment to energy options: case study of KARTAMANTUL region, Yogyakarta. Renew Energ. 2012;41:277-84

24. DAEDE. Thailand needs to promote energy from waste. Bangkok: Department of Alternative Energy Development and Efficiency; 2012.

25. Intergovernmental Panel on Climate Change. Climate change 2013: the physical science basis. Cambridge and New York: Cambridge University Press; 2013.

26. Hogg D, Ballinger A. The potential contribution of waste management to a low carbon economy. Bristol: Eunomia Research \& Consulting Ltd; 2015.

27. USEPA. Available and emerging Technologies for Reducing Greenhouse gas Emissions from municipal solid waste landfills. Research Triangle Park: US Environmental Protection Agency; 2011

28. Arena U, Di Gregorio F. A waste management planning based on substance flow analysis. Resour Conserv Recy. 2014;85:54-66.

29. Christensen TH, Gentil E, Boldrin A, Larsen AW, Weidema BP, Hauschild M. C balance, carbon dioxide emissions and global warming potentials in LCAmodelling of waste management systems. Waste Manage Res. 2009;27:70715.

30. RTI. Greenhouse Gas Emissions Estimation Methodologies for Biogenic Emissions from Selected Source Categories. Research Triangle Park: Research Triangle Institute; 2010

31. Menikpura SNM. Development sustainability indicators for evaluating municipal solid waste management systems - LCA perspective [Ph.D. dissertation]. Bangkok: King Mongkut's University of Technology Thonburi; 2011.

32. Brunner $\mathrm{PH}$, Rechberger $\mathrm{H}$. Practical handbook of material flow analysis. Boca Raton: Lewis Publishers; 2004.

33. Intergovernmental Panel on Climate Change. 2006 IPCC guidelines for National Greenhouse gas Inventories. Kanagawa: Institute for Global Environmental Strategies; 2006.

34. Intergovernmental Panel on Climate Change. Climate change 2007: mitigation of climate change. Cambridge and New York: Cambridge University Press; 2007.

35. Chanchampee P. Methods for evaluation of waste management in Thailand in consideration of policy, environmental impact and economics [Ph.D. dissertation]. Berlin: Technische Univ; 2010.

36. Wernet G, Bauer C, Steubing B, Reinhard J, Moreno-Ruiz E, Weidema B. The ecoinvent database version 3 (part I): overview and methodology. Int J Life Cycle Assess. 2016;21:1218-30.

37. Rand T, Haukohl J, Marxen U. Municipal solid waste incineration: Requirements for a Successful Project. Washington: The World Bank; 2000.

38. Menikpura SNM, Sang-Arun J, Bengtsson M. Assessment of environmental and economic performance of waste-to-energy facilities in Thai cities. Renew Energ. 2016;86:576-84.

39. Laurent A, Clavreul J, Bernstad A, Bakas I, Niero M, Gentile E, et al. Review of LCA studies of solid waste management systems - part II: methodological guidance for a better practice. Waste Manag. 2014;34:589-606.

40. Goedkoop M, Heijungs R, Huijbregts M, De Schryver A, Struijs J, van Zelm R. ReCiPe 2008, A Life Cycle Impact Assessment Method Which Comprises Harmonised Category Indicators at the Midpoint and the Endpoint level: First Edition Report I: Characterisation. Bilthoven: National Institute for Public Health and the Environment; 2013.

41. Lamnatou C, Ezcurra-Ciaurriz X, Chemisana D, Pla-Aragones LM. Environmental assessment of a pork-production system in North-East of Spain focusing on life-cycle swine nutrition. J Clean Prod. 2016;137:105-15.

42. Kral U, Kellner K, Brunner PH. Sustainable resource use requires "clean cycles" and safe "final sinks". Sci Total Environ. 2013;461:819-22.

43. Mastellone ML, Brunner PH, Arena U. Scenarios of waste management for a waste emergency area. J Ind Ecol. 2009;13:735-57.

44. Chaya W, Gheewala SH. Life cycle assessment of MSW-to-energy schemes in Thailand. J Clean Prod. 2007;15:1463-8.

45. Cleary J. Life cycle assessments of municipal solid waste management systems: a comparative analysis of selected peer-reviewed literature. Environ Int. 2009;35:1256-66
46. Liamsanguan C, Gheewala SH. Environmental evaluation of MSW management in a life cycle perspective. Chennai: The International Conference on Sustainable Solid Waste Management; 2007 Sep. p. 5-7.

47. Lakioti EN, Moustakas K, Komilis DP, Domopoulou AE, Karayannis VG. Sustainable solid waste management: socio-economic considerations. Chem Eng Trans. 2017;56:661-6.

\section{Publisher's Note}

Springer Nature remains neutral with regard to jurisdictional claims in published maps and institutional affiliations.
Ready to submit your research? Choose BMC and benefit from:

- fast, convenient online submission

- thorough peer review by experienced researchers in your field

- rapid publication on acceptance

- support for research data, including large and complex data types

- gold Open Access which fosters wider collaboration and increased citations

- maximum visibility for your research: over $100 \mathrm{M}$ website views per year

At BMC, research is always in progress.

Learn more biomedcentral.com/submissions 